\title{
Shamanistic and Postshamanistic Terminologies in Saami (Lappish)
}

\author{
BY HÅKAN RYDVING
}

\section{Introduction}

The study of the lexicon of a language, of special semantic fields, changes in the meaning of words and comparisons between the lexicon or parts of it in different dialects can provide valuable complements to other types of sources. This is nothing new, and the study of Saami cultural history is in this respect no exception. A number of papers have thus dealt with different parts of the Saami lexicon, central for the understanding of various aspects of Saami culture. Knut Bergsland (Bergsland 1942), Johannes Falkenberg (Falkenberg 1953) and Ian Whitaker (Whitaker 1979) have e.g. presented kinship-terminologies and Nils-Erik Hansegård (Hansegård 1978) has treated words referring to permanent settlement; the terminologies of fishing, furs and skins, handicraft and weaving have been dealt with by Asbjørn Nesheim (Nesheim 1947; Nesheim 1964; Nesheim 1967; Nesheim 1954); Israel Ruong (Ruong 1945, 186-193; Ruong 1964, 75-92; Ruong 1982) has discussed reindeer colour and snow terminology and names for nonSaamis, Pekka Sammallahti (Sammalahti 1982) hunting-terms and Bo Wickman (Wickman 1965) the hunting and fishing terminology. We cannot here devote space to any history of research in this field. Suffice it to note that perspectives and methods differ and that religious terminologies have not come under examination.

The most important sources for the study of pre-Christian Saami religion, the so called "prästrelationer"' 'priestrelations', are indirect, but, although language could be reckoned as a direct and primary source, Saami linguistics can only function as a means of assistance for the history of religions. It is scarcely possible to draw solid conclusions about Sami religion, solely on linguistic evidences, although different types of linguistic arguments can be used to supplement what has been concluded with the help of other source categories.

The purpose of this paper is to draw attention to a problem of source criticism that faces the student of Saami shamanism and is caused by the changes of meaning which words used in the shamanistic context underwent in the period of religious change, i.e. the $17 \mathrm{th}, 18$ th and (to some 
extent) 19th centuries. These changes of meaning render our possibilities of understanding the shamanistic aspects of the pre-Christian Saami religion more difficult as they make it hazardous to draw conclusions about shamanism from what we know about the use and meaning of these words in the later terminologies of magic.

The study of the terms of what in Saami is called noai' děvuottâ ${ }^{1}$ 'what has to do with the noai' de' to some extent involves different problems to the study of the terminologies of e.g. hunting or handicraft. New huntingmethods have certainly replaced older ones that turned out to be less effective, and handicraft has, through access to new materials, broken new ground, but this does not mean that the older hunting or handicraft terminologies in some way have become "taboo" in the same way as the terms that were used in the old religion. Neither is it so that those who have given us the most important source material on let us say Saami bird-hunting, had as their main task to introduce new hunting-methods or replace bird-hunting with some other kind of hunt or another source of livelihood. That is obviously the case, however, when we are studying Saami religion. The sources from the 17 th and 18 th centuries derive almost exclusively from persons whose mission in life was to replace the Saami religious rites and conceptions with new ones.

This is certainly true; but given the conditions and presuppositions of the time, what is remarkable is that we after all know as much as we do, something that of course is due to the fact that the main interest of the missionaries was-religion.

\subsection{Preliminaries}

Before proceeding, it is necessary to draw some essential distinctions in meaning and mention the delimitations I have made. I will therefore briefly define the terms in the heading: 'shamanistic', 'postshamanistic' and 'terminology'.

Definitions of shamanism are legio and historians of religions sometimes

\footnotetext{
${ }^{1}$ Saami words are, if not otherwise stated, given in $1 p N$ form according to the orthography used in Nielsen 1932-38. As for the other dialects the orthographies that have been used are Grundström 1946-54 for lpL, Schlachter 1958 for lpU and Hasselbrink 1981-85 for lpS, while the spellings used in Itkonen 1958 and Lagercrantz 1939 have been simplified conventionally. Words that are given in the same form as in the older sources are printed in boldface. Russian words are transliterated according to the system used by the British Museum.

The designations for the dialect-groups and dialects have been abbreviated in the usual way. Dialect-groups: $l p S$ : Southern Saami, $l p C$ : Central Saami and $l p E$ : Eastern Saami; dialects: lpU: Ume Saami, lpL: Lule Saami, lpN: Northern Saami, lpI: Inari Saami, lpSk: Skolt Saami, lpKld: Kildin Saami, lpTer: Ter Saami.

The examples of words are in the main given in order of provenance from $1 \mathrm{pS}$ to $1 \mathrm{pE}$.
} 
have a tendency to talk as if 'shamanism' were something concrete, thereby forgetting that it only exists as an abstraction and a concept in the brains of its students. In this paper I have used Åke Hultkrantz' definitions of 'shaman' as " a social functionary who, with the help of guardian spirits, attains ecstasy in order to create a rapport with the supernatural world on behalf of his group members" (Hultkrantz 1973, 34) and 'shamanism' as "the complex of beliefs, rites and traditions clustered around the shaman and his activities" (Hultkrantz 1973, 36). These definitions have been my point of departure, but I have, because of the limited space here at my disposal, left out the words for different guardian spirits and also words for the Saami drum. ${ }^{2}$ The words here discussed are then designations for the shaman and his activities. Unfortunately, only a few words of this kind are known from the earlier sources, and students of Saami shamanism have used words from later sources to compensate for this shortage, even though for example Nikolaj Kharuzin (Kharuzin 1890), ${ }^{3}$ Toivo I. Itkonen (Itkonen 1946) and Louise Bäckman (Bäckman 1978) have clarified the differences between the noai'de as 'shaman' in the old religion and the noai'de as 'diviner' and 'magician' in the postshamanistic period. As I have already indicated, my purpose is to discuss some aspects of this change of meaning.

If 'shamanism'-in spite of the discussions about its definition-is well grounded as a concept in the history of religions, postshamanism is a more dubious term. I have used it in order to emphasize both the continuity, when the same words are used, and the differences in meaning between the words as used within the shamanistic segment (this wording after Hultkrantz 1973, 37) of the pre-Christian religion and these same words when later used to denote functionaries and practices in the magic sphere. But I have also included words that are not found in the sources of the old religion, words that in later sources are translated in the same way as these, i.e. other words for 'diviner', 'sorcery', 'witch' etc. Some of these words might, although they are not found in the older source material, have been used earlier in shamanistic contexts, but most of them have no doubt never had any connection with shamanism. From what I have said, it is apparent that I wish to stress the religious roles of the noai'de as the shaman in the

\footnotetext{
${ }^{2}$ It is my intention to discuss the understanding of the concepts of 'soul' and 'spirit' in Saami in another paper.

${ }^{3}$ I have had no access to Kharuzin's paper "O noidakh u drevnikh i sovremennikh loparei" 'On noai' de's among former and contemporary Lapps' in Ethnograficheskoe obozrenye 1889, but according to a note (by K. B. Wiklund ?) in the copy of Kharuzin 1890 that is kept in the university library in Uppsala, the contents of the paper are totally included in the fourth chapter of the book.
} 
indigenous Saami religion, in contrast to the noai'de-magician after the change of religion, a view that will be discussed briefly later. ${ }^{4}$

Out of convenience I have used terminology in no strict philosophical meaning, but in the general sense of 'a system of terms' and it should be noted that I have not aimed at completeness, but only tried to exemplify the contents of the terminologies under examination.

\subsection{Sources}

As sources for this presentation I have gone through the printed source material from the 17 th and 18 th centuries, printed oral traditions from the different dialect-areas and dialect-dictionaries. Taken as a whole the material gives an indication of the disparity of the different contexts that had the noai'de at their centre.

\section{Words}

The shamanistic terminologies in the Uralic languages show, contrary to e.g. the hunting and fishing terminologies, a surprisingly small common vocabulary. This is, at least partially, explained by our inferior knowledge of these terminologies. Those who collected and wrote our sources, as representatives of an alien religion, naturally had difficulties both in getting access to and in understanding more deeply the shamanistic aspects of the indigenous religions. Obviously, only a small part of the words used in the shamanistic contexts have been preserved.

A special problem with the shamanistic terminology in Saami has to do with the negative connotations by which even the earliest sources are marked. Hence, the Saami words are translated with 'conjure', 'enchantement', 'sorcerer', 'sorcery', 'witchcraft', 'wizard' etc., a tendency that, as Louise Bäckman has observed, "has coloured the general view of the noaidi" (Bäckman 1978, 86).

The following presentation of words is structured so that the first section is devoted to words found in the sources from the 17th and 18th centuries, the second to a comparison of some passages in the translations of the Bible from 1811 and 1895 , whilst the third presents words from later sources and also briefly discusses the origins of the terms.

\footnotetext{
${ }^{4}$ For a discussion of the problems of the drawing of the borderline between religion and magic, see Widengren 1969, 1-19.
} 


\subsection{Examples of words found in sources from the 17th and 18th centuries}

The common word for the Saami shaman in the earlier sources is noai'de, but, strangely enough, there is no record of the word in the Swedish sources from the 17th century. Not even Lundius who knows sueie to be the name of the guardian spirits and kwepckas the word for 'a woman versed in black art' (Lundius [late 1670's] 1905, 6, 8) has anything to say. The reason for this is probably the general tendency of the pre 18th century sources to attribute the skills of the noai' de to most Saamis (Bäckman 1978, $71 \mathrm{f}$.).

The word is however well attested in the sources from the 18th century and translated in various ways as e.g. ' 'prophet, diviner, sorcerer' (Randulf [1723] 1903), 'priest and prophet of sorcery' (Skanke [1728] 1945, 205; Skanke [1731] 1910, 104), 'a wise man, a diviner' (Kildal [1730] 1945, 105), 'sorcerer, wise man' (Leem 1767), 'witchprophet' (Jessen 1767) and 'sorcerer, diviner' (Lindahl \& Öhrling 1780).

Of the derivations (see further 2.3 below) to noai' de Lindahl \& Öhrling (Lindahl \& Öhrling 1780) mention: nåitats 'a small diviner', nåiteswuot 'black art', nåitot 'conjure' nåitom 'witchery', nåitostet diminutive to nåitot, nåitogåtet 'begin practising sorcery', nåitotet 'bewitch', nåitotem 'bewitching', naiitastallet 'practise sorcery, $[\ldots]$ boast of, that one can conjure', nåitastalleje 'one that practises sorcery or boasts of his/her sorcery', nåitastallem 'sorcery' and naites 'what has to do with sorcery and witchery' as in the compositions nåites pargo 'witchery', nåites ålma 'wizard, diviner' and nåites did 'ritus magicus'.

Although it is doubtful whether lpL kuopas denoted a shaman proper (Bäckman 1978, 84) this female is treated in connection with the noai' de in the sources, and I therefore list a few of the explanations here: kwepckas 'woman versed in black art' (Lundius [late 1670's] 1905, 8), guaps 'a woman that could chant and divine on the instruments that her sex had access to' (Skanke [1728] 1945, 200; Jessen 1767, 46, with the misprint /?/ Guape),

\footnotetext{
${ }^{5}$ Finnish, German, Norwegian and Swedish words in the examples have, for the sake of homogeneity, been translated into English according to the following outline: bewitch (verzaubern, förtrolla), bewitching (förtrollande), black art (svartkonst), conjure (noitua, zaubern, trolla), divine (wahrsagen, spå), diviner (Wahrsager, runemand, spåman), enchanting (zauberisch), enchanting song (Zauberlied), female fortune teller (Weissagerin, spaaeqvinde), practise sorcery (harjoitta noituutta, bruka trolldom/trolleri), priest (praest), prophet (prophete), shaman (Schamane, schaman), sibyl (signekone), sorcerer (Zauberer, troldman, trollkarl), sorceress (Zauberin/Zauberweib, troldqvinde, trollkvinne), sorcery (noituus, Zauber/Zauberei, troldom, trolldom/trolleri/trollkonst), troll-drum (Zaubertrommel, trolltrumma), wise man (viismand), witch (Hexe, hex, häxa), witchery (häxeri), witch-prophet (hexe-prophete), wizard (Hexenmeister, häxare/häxkarl).
}

The words are easily found with the help of the source-references. 
gwopes 'sorceress' (Lindahl \& Öhrling 1780). Lindahl \& Öhrling (Lindahl \& Öhrling 1780) mention two derivations of the word: gwopeswuot 'sorcery' and gwopastallat 'conjure'. The word gapishjaedne in Leem (Leem 1768) 'a female fortune-teller, sibyl, witch, sorceress' is most likely a composition of 1pL kuopas and iedne 'mother' (see further, section 2.3.2. below).

A third word ought to be mentioned: Leem's (Leem 1767, 486) judakas or juraak 'a sorcerer that never chanted'. It is probably connected with $\operatorname{lpN}$ jurrâ 'noise, hum, rumbling, crashing' (Nielsen 1932-38), a word that is likely a Finnish loan-word (cf. Finnish jyry 'rumbling'; Toivonen et al. 1955-81, 128), and in all probability characterizes the seance of the shaman.

After these indications of what is known of the shamanistic terminologies in Saami, we now turn to the sources of postshamanism and first to some extracts from Saami Bible-translations.

\subsection{Examples from translations of the Bible}

To translate biblical (and other religious) texts into Saami was an important method for the Christian mission, ${ }^{6}$ and the words used in the translations were very likely chosen with great care in order to establish connections with Saami thought. Consequently, one could use the translations in order to get an idea of (how the translators at least conceived) the meanings of the Saami words. I have gone through those verses in the translations of the Old Testament from 1811 and 1895 respectively, where Arvid S. Kapelrud (Kapelrud 1967) believed there were to be found what he calls 'shamanistic features', thereby hoping to find suitable examples. And, interestingly enough, the word noai'de is found in several of these passages in the translation from 1811:

1 Sam 28:3 1811: "[...] ja sardnoin etjebse årrot nåiten [...]" 'and called themselves noai'de's'

Is $3: 21895:$ "'[..] ja diettes olbmaid [...]" 'and men good at knowing" noai'de's' and old men'

1895: "[...] profeta ja einostægje ja vuorrasa [...]" "prophet and diviner and elder'

Is $8: 19$ 1811: “[...] ja nåitemeb [...]" 'and noai' de'

1895: "[...] ja diettes olbmai [...]" 'and a man good at knowing'

Is 44:25 1811: “[...] takkab nåitit wadn-miälakin [...]"' 'make noai'de's witless'

1895: "gutte dakka [...] einostegiid jallan [...]" 'that make diviners stupid"

\footnotetext{
${ }^{6}$ Of the literature in Saami printed before 1899, 173 out of 290 items (if the 106 calendars are excluded) are different religious texts such as bible translations, service- and prayerbooks, catechisms and books of homilies (Qvigstad \& Wiklund 1899, 135).
} 
Jer 27:9 1811: “Alet kuldele (kula) Profetaitete, kättojitete, päketejitete, åutoi-tjälgestejitete ja nåitite [...]" 'Do not listen to your prophets, your diviners, your [?], your self-explainers or your noai'de's'

1895: "Ja di, allet gulddal din profetaidædek ja din einostegjidædek ja din niegoidædek ja din mærkkačilggijegjidædek ja din guvllaridadek [...]' 'And you, do not listen to your prophets or your diviners or your dreams or your soothsayers or your quack-doctors'

Jer 29:8 1811: "[...] ja nåititete [...]" 'and your noai' de's'

1895: "[...] ja din einostegjidædek [...]" 'and your diviners'

That noai' de only occurs in the older translation, but corresponds to einustag'gje 'diviner' ( 3 times), diet'tes olmai 'a man good at knowing' (twice) and guwlar 'quack-doctor' (once) in the translation from $1895 \mathrm{might}$ be an evidence of the greater proximity to the old religion in 1811 , but could also be explained by different attitudes of the translators to connections with pre-Christian religious ideas or by the different dialects that are used in the translations.

\subsection{Examples of words in postshamanistic terminologies}

Turning to other sources from the Christian period, it is important to note that words from the shamanistic terminologies of the pre-Christian religion are still used, but with the new meanings and in the new context of postshamanism.

\subsubsection{IpN noai'de}

The word with the widest distribution occurs in Northern Saami as noai'de and is found in all Saami dialects (in the present orthographies of the literary languages: $\operatorname{lpS}$ nåejtie, $\mathrm{lpL}$ noajdde, $\mathrm{lpN}$ noaidi, $1 \mathrm{pI}$ noaidi, $\mathrm{lpSk}$ nåidd), in Finnish (noita) and in the other Finnic languages. The occurence in Mansi (ńajt), an Ugric language, shows that it could be reckoned as Finno-Ugric (Collinder 1977, 117), and thereby, according to the prevalent (approximate and uncertain) datings, belonging to the stratum of Saami words that are reckoned to be at least 4000 years old (Wickman 1965, 503; cf. Korhonen 1976). It is worth observing that nothing can be said of the possible changes of meaning that the word may have gone through, but as the word has about the same meaning in both the westernmost (Saami) and easternmost (Mansi) language where it occurs, one could be tempted to assume that the meaning and consequently what the word stands for should be of the same age.

Noai'de is translated in roughly the same way in the different dictionaries: 
nuojtie 'diviner, sorcerer' (Snåsa, Tysfjord, Karesuando, Lyngen, Nesseby) (Lagercrantz 1939), lpS: noåjdie '1. sorcerer, wizard; 2 . one being in charge of the trolldrum (gievrie)' (Härjedalen, Oviken, Vilhelmina) (Hasselbrink 1981-85), lpU: nåỳ dee 'sorcerer' (Schlachter 1958), lpL: nåi'tē 'sorcerer, shaman' (Grundström 1946-54), lpN: noai' de 'sorcerer, wizard' (Nielsen 1932-38), lpE: noaid 'sorcerer' (Pasvik, Petsamo, Nuortijärvi, Kildin, Ter) (Itkonen 1958).

2.3.1.1. Derivations of and compositions to noai'de.-Saami is a language rich in derivations. While compositions are formed spontaneously, derivations are looked upon as individual words (Nickel 1984, 181). They are therefore found in dictionaries and consequently dominate this presentation. The words are of varying age. Some occur in the whole Saamispeaking area, which makes it possible to assume that they are older than those only found in one or two dialects.

Among the derivations found in all the dialects is the previously mentioned noai' dévuottâ 'sorcery, witchcraft, magic', a word that, during the time of the old religion, was perhaps the Saami word that was nearest in meaning to the modern abstract 'shamanism'.

The verb that is best supported in the sources is noai'dot:

noåjtot 1. 'sing an enchanting song' (Tännäs), 2. 'divine' (Snåsa), 3. 'conjure' (Arjeplog, Karesuando, Lyngen) (Lagercrantz 1939), lpS: noåjdudh 1. 'conjure' (Vilhelmina, Offerdal), 2. 'sing an enchanting song' (Frostviken, Undersåker, Härjedalen), 3. 'beat the troll-drum (gievrie)' (Oviken), 4. 'divine' (Snåsa) (Hasselbrink 1981-85), lpU: nåỳdoot 'conjure' (Schlachter 1958), IpL: nåi'tot 'conjure, practise sorcery'; in Southern Gällivare also 'bewitch' (Grundström 1946-54), lpN: noai' dot 'practice sorcery, witchcraft' (Nielsen 1932-38), lpSk: noaidat 'conjure, practice sorcery' (Pasvik, Suonikylä) (Itkonen 1958).

Another verb is $1 \mathrm{pN}$ noaidastâd'dât or noaidastâllât 'practice sorcery, magic' (Nielsen 1932-38), lpL 'give an air of knowing how to conjure' (Grundström 1946-54; lpE momentan-diminutive-frequentative in Pasvik and Kildin according to Itkonen 1958). The present participle of this verb noaidastâl'le means accordingly 'sorcerer, sorceress' (Lyngen) (Lagercrantz 1939), 'someone that is practicing sorcery or wants to appear as sorcerer' (Jokkmokk) (Grundström 1946-54).

Two examples of compositions (in the Eastern Saami forms from Nuortijärvi) are noitkalles 'old noai'de-man' and noitahk'k' 'old noai'de-woman' (Itkonen 1958).

Beside words that are found in all the dialects, there are also words with a more limited distribution. In Southern and Ume Saami there is, for example, the adjective $1 \mathrm{pS}$ noåjdies 1. 'enchanting (man)' (Tännäs), 2. 'someone that can divine' (Snåsa) (Lagercrantz 1939), 'enchanting (man), someone that can divine' (Stensele, Härjedalen, Snåsa) (Hasselbrink 1981-85), 'sor- 
cery-' (Schlachter 1958). The word is used as the first component in compositions like $\mathrm{lpS}$ noåjdiesaakkaa 'sorceress, witch' (Stensele), noåjdiesbaarnie 'son of a sorcerer' (Stensele) and noåjdiesgåmmaa 'witch, female fortune teller' (Frostviken) (Hasselbrink 1981-85), 'sorceress' (Schlachter 1958). Another exemple of a southern word is noajjume 'sorcery' (Røros) (Hasselbrink 1981-85).

From Central Saami dialects one could mention noai'dohit 'cause enchantment', and from this noai'dohag'gje 'someone that causes someone elses enchantment' that Lagercrantz (1939) has recorded in Lyngen and is also known in Lule Saami: 'enchant' (Northern Gällivare; causative to nåi’tot in Jokkmokk) (Grundström 1946-54). Ume Saami nùidadahka 'brought about by sorcery' (Schlachter 1958) is also attested in Lule Saami, but there with the meaning 'sorcery' (Grundström 1946-54).

There are also some words that are only recorded in Eastern Saami dialects. Examples are noitmaš 'sorcery' (Nuortijärvi) and noitlaššat 'conjure, practise sorcery' (Nuortijärvi, Pasvik) with the form noaideluašsat 'conjure (keep membling an enchanting song in one's sleep)' also known from Pasvik (Itkonen 1958).

\subsection{2.. lpL kuopas}

Locally in Lule Saami there is together with noai'de another word also known from the earlier sources (cf. 2.1 above): kuopas. Grundstrom (Grundström 1946-54) says that it is rarely used and translates it as 'sorcerer, sorceress' (Gällivare), 'skilled in the sorcerer's/ sorceress's art (seldom about men)' (Jokkmokk). As a derivation of kuopas he mentions kuopastallat 'conjure' (Gällivare), "want to be regarded as skilled in the sorceress's art' (Jokkmokk), and in lpU there is a word for 'troll-drum' that is a composition to this word: guaps-gåb'dee (Schlachter 1958). The word is notable as Samuel Rheen (Rheen [1671] 1897, 35), writing about the adjacent Lule Lappmark, emphasizes that women were forbidden even to touch the drum. Whether the contradiction is due to regional differences or to changed attitudes is difficult to say, but the word should be born in mind in discussions about whether there were female shamans among the Saamis or not.

It is often difficult to localize the information that is given in the earlier sources, but with the help of dialect geography this is sometimes possible. Kuopas can exemplify this possibility to determine from where a word, and thereby a conception, comes, since-because of its current distribution-it can be defined as Lule and Ume Saami. But one should of course bear in mind that language is not static, and that the dialectal distribution of a word can be changed for various reasons.

13-869071 Saami Religion 
Nesheim (Nesheim $1970 a, 22)$ has compared the word with 1pL kuobbit 'turn the eyes inside out, glare, stare angrily', an etymology that, because of the phonetic conditions, is rather uncertain. Another suggestion is to connect the word with Mari kuva 'old woman' and Udmurt kuba 'motherin-law'. The word would then be Finno-Permian. If this etymology, which Toivonen et al. (s.v. kave) quotes with some hesitation, is correct, the word could be compared with the words used as second element in compositions translated 'sorceress, witch' etc. These words often denote an 'old woman', as e.g. IpN ak'ko or lpS gåmmaa.

\subsubsection{Other words for diviner, sorcerer etc.}

$\mathrm{LpN}$ noai' $d e$ and $\mathrm{lpL}$ kuopas are in the postshamanistic terminologies only two of a large number of words that denote different diviners, sorcerers etc. The vocabulary is very rich and it is here only possible to give some examples.

A word found in Southern and Central Saami is the Nordic loan-word guwlar (cf. Swedish kucklare, Qvigstad 1893, 184) 'quack-doctor' (Karesuando, Enontekiö, Utsjoki, Nesseby) (Lagercrantz 1939), 'who cures people with the help of conjurations, the laying of hands etc. (not with medicine)' (Grundström 1946-54), 'who does magic, does quack cures (by magic)' (Nielsen 1932-38).

In Central Saami dialects one finds words such as $1 \mathrm{pN}$ diet'te '[. ..] who knows a thing or two, versed in magic' and (čâlmě-) gaei'do 'one who bewitches people's sight' (Nielsen 1932-38; also in lpL, Grundström 1946-54; from Finnish silmänkääntäjä) and 1pL skäddar with the same meaning (Grundström 1946-54).

The Eastern Saami dialects have their special words for 'diviner' and 'sorcerer', as well. In Kildin the word for 'rock or stone which has been an object of worship' (Nielsen 1932-38, lpN siei' de) has the subordinate sense 'sorcerer' and in Pasvik there is a word sahple-lijjen-jotti 'sorcerer' (that at the beginning of a journey sends out a mouse as reconnoitrer; if the mouse is killed, the sender will also die). The Russian loanword eretnik 'heretic' is used in the same dialect in the sense 'sorcerer; troll'. The word kebun that Korol'kov (Korol'kov 1908, 162) mentions, has also been looked upon as a Russian loan-word (Kalima 1930), but is more probably a slightly corrupt Saami form of a derivation of a word corresponding to $\mathrm{lpN}$ gievvot (Äimä 1932; se further 2.3.4 below).

An interesting word is lpTer käirve or käivre 'sorcerer', Ip Kld kivr 'sorcerer, heretic', according to Itkonen (Itkonen 1958) related to the name of a god, Kārva. It is, as far as I know, the only example of a possible theistic association among these words. The gods have otherwise no roles to play either in Saami shamanism or in the magic of postshamanism. 


\subsubsection{Words denoting characteristics and activities of the noai'de}

Although ecstacy is a central element in shamanism, it is usually said that there is no Saami word for ecstacy and if only nouns are taken into consideration this might be true, but there are two verbs that denote ecstatic states: $1 \mathrm{pN}$ gievvot and $1 \mathrm{pE}$ kikkat.

Nielsen (Nielsen 1932-38) translates gievvot as "behave as if one is in an ecstasy (e.g. of one who is under the influence of profound religious emotion); be wild' (Kautokeino) and Grundström (Grundström 1946-54) gives the meaning 'be out of one's senses in emotion or hysteria (?)', with the addition that in Jokkmokk it is used for 'wrath, particularly women'. Also Laestadius discusses the word and translates it 'be wild or furious, or behave like mad' (Laestadius [1840-45] 1959, 98). Äimä shows in his investigation of the word, although it is to a great extent built on the theories about an 'arctic hysteria' prevalent at the time, that gievvot is connected with ecstatic states. Even though it is impossible to know if this word was used about the shamanistic ecstacy, it is hardly rash to assume that an existing word for 'ecstacy' could also have been used in religious contexts (Äimä 1932, a list of derivations on $411 \mathrm{ff}$.). According to Toivonen et al.(Toivonen et al. 1955-81, 189) the word is possibly Finno-Ugric, but the etymology is uncertain.

The other verb is even more interesting as it has clear connections with shamanism. LpE kikkat means 'play, sound (capercailzie courting)', in Nuortijärvi, Kildin and Ter also 'sing, hum (ecstatic sorcerer)' and in Ter 'conjure' as well (Itkonen 1958). It denotes in Central Saami the pairingsound of animals, the amorous call of birds (and particularly capercailzie, Tetrao urogallus) ${ }^{7}$ and in the dialects of the Kola peninsula also the sound of the noai'de during ecstasy (an onomatope for this sound is in lpTer kharr-kharr; Itkonen 1958). The word is Finno-Ugric, and e.g. related to words in Khanty and Mansi with clear shamanistic connotations (Collinder 1977, 96).

As these two words are in all probability indigenous, they were used during the time of the old religion, and then, possibly in the shamanistic context.

There are, to be sure, many other nouns and verbs that denote different activities of and circumstances connected with the noai'de. For some this is their primary sense (a few examples are given under $a$ below), while others are only attested with a connotaton connected with noai'de in one or two of the dialects ( $b$ below).

\footnotetext{
${ }^{7}$ Prof. Lars-Gunnar Larsson has informed me that the capercailzie, during a certain part of its courting is blind and deaf, i.e. in a state of हैxoroors!
} 
(a) In Wefsen (lpS) a word västies means 'evil, enchanting' according to Lagercrantz (Lagercrantz 1939), and from Tysfjord (lpL) he has recorded kanna, translated as 'magic power', borrowed from Norwegian gand (Qvigstad 1893, 164).

Another Nordic loan-word (Qvigstad 1893, 128) is tii' dâ 'magic act, sorcery, superstitious practice' (Arjeplog, Nesseby) with derivations such as tii' dit 'undertake magic acts, conjure' (Nesseby), tii' distâllât 'undertake magic acts, conjure' (Arjeplog) (Lagercrantz 1939) and tiidâstâllât 'divine with the help of signs, practise superstition, be superstitious' (Grundström 1946-54).

In $\mathrm{lpN}$ one finds gai' det '(supernaturally) make invisible or cause to assume the appearance of something else (by bewitching the sight)' (Nielsen 1932-38), 'bewitch, make invisible through a sorcery' (Nesseby) (Lagercrantz 1939) and juovsâtit 'through a sorcery bring back, gather and let return to the possessor' (Lagercrantz 1939; Nielsen 1932-38). A causal informant from Polmak translates the last word as 'employ magic to make wild reindeer assemble and come to the place where one is lying asleep oneself (of noai'de in old days; [...])' (Nielsen 1932-38), and in lpTer palledit "participate/co-operate in enchanting songs ("while the sorcerer hums in ecstacy- kikka-, his assistants reiterate and beat the sorcerer with the flat of the hand on the back of his neck')' (Itkonen 1958).

(b) The second category, words with (local) connotations that denote activities and characteristics of the noai'de, but otherwise have other and more neutral meanings, could be exemplified by some $1 \mathrm{pC}$ words.

The teeth were important as a sign of the power of the noai'de, and it is therefore rather natural that bānětuvvât in $1 \mathrm{pN}$ besides 'become toothless' also means 'lose the power to practise sorcery, magic' and consequently bānĕtabmé 'toothless' has the subordinate sense 'who has lost the power to practise sorcery, magic' (Nielsen \& Nesheim 1962-69, 5, 109).

The word borrât 'eat; bite' is, as is already known from Olsen (Olsen [after 1715] 1910, 96), used when someone kills by sorcery and the strongest noai' de's were called borâ-noai'de 'eating-noai' de (e.g. according to Qvigstads' informant J. J. Aikio [born in Inari in 1855], Qvigstad 1927, 440; cf. 3.2 below). This word, too, shows the significance of the teeth. ${ }^{8}$

In Central Saami dialects the Nordic loan-word goan'stâ (Qvigstad 1893, 174; cf. Swedish konst) besides 'art' also means 'art of magic' (Nielsen 1932-38, Grundström 1946-54).

\footnotetext{
${ }^{8}$ A comparison between these last words and kuopas (2.3.2 above) gives the opportunity to pose the question of differences between the sexes, as it seems as though men should be young (still have their teeth) but women (if the proposed etymology to kuopas is correct) old.
} 
An Eastern Saami example is the Nordic loan-word murret (Qvigstad 1893, 241; cf. Swedish morra) that in many dialects has the same meaning as in the Nordic languages ('growl'), but from Pasvik it is recorded as 'hum (sorcerer in his sleep)' (Itkonen 1958).

Finally, let us turn to some examples from the dialect in Lyngen. These words were recorded by Eliel Lagercrantz when he investigated the dialect in November 1919 and during the autumn of 1920 (Lagercrantz 1939, 1201).

An example of a word which in other dialects has a more neutral meaning, but here has a special sense is the derivation juoigâstit (of juoi'gât 'sing in the Lapp style', Nielsen 1932-38) that is translated 'bewitch'.

Loans from Norwegian are e.g. lapmat and mânidit. Lapmat denotes the motion of the blood of the sorcerer, which moves around the body of the enchanted man, and the passive derivation labmujuvvot means 'bewitch'. Mânidit 'affect through sorcery' and the derivations mânidacd' $d$ ' $i$ 'sorcerer, that through sorcery and magic acts drives away diseases etc.', mânidxpmi 'sorcery, magic chasing away', mânidahtit 'drive away through sorcery' and mânidahtihahti 'possible to affect through sorcery' have been borrowed with Finnish manata 'call forth, conjure up (spirits)' as intermediary (Lagercrantz 1939; Qvigstad 1893, 204, 231; cf. Norwegian kluma and mana).

Other words from Lyngen are e.g. pijjehakat 'sorcery', påjjidit 'caused by sorcery', tajka 'sorcery, magic act' and tajkkastallat 'conjure' (Lagercrantz 1939).

\subsection{Some concluding remarks}

The words that have been used here to illustrate the contents of the shamanistic and postshamanistic terminologies in Saami are only examples from some parts of the terminologies and represent words for the shaman/ /diviner and his activities. The material is, because of the different sources, not uniform. Much less is known about shamanistic than about postshamanistic terms, and the dominance of Northern Saami material is not solely due to a greater abundance of terms in those dialects (although that really seems to be one of the reasons). It is accordingly slightly hazardous to draw conclusions. Well aware of the fact that a more extensive examination could give other results, I think that it is at least possible to gather three tendencies from the material:

1. There seem to be great regional differencies in the postshamanistic terminologies, with various words for e.g. types of diviners in different regions, but we cannot from this conclude that there were similar differences during shamanistic times.

2. Nordic loan-words are most common in Northern Saami, a tendency 
well known also for other word-categories and other cultural traits. This region seems to have been an important area for cultural contacts and innovations.

3. Words used in the shamanistic terminologies proper (denoting the shaman and his ecstacy) are inherited to a greater extent than words used in the postshamanistic terminologies (that denote the diviner and his practices).

Indeed, the lexicon of a language is never static, but undergoes continual changes. Old words go out of fashion and new words, derivations and compositions, borrowings and translation loans, come into vogue. A point that should be born in mind when one is considering loan-words is that the loan of a word does not necessarily mean that the phenomenon the word denotes has also been borrowed. Reasonings based on loan-words cannot be used in isolation as criteria for cultural borrowings, but must be supplemented by other arguments. That the terminology of magic in Saami to a great extent is borrowed, does not necessarily mean that magic as such is also borrowed, although separate techniques may have been borrowed together with the words that denote them.

\section{Terminologies}

So far, we have looked only at the words occurring in the Saami shamanistic and postshamanistic terminologies from the point of view of singular words. It is now time, however, to discuss some examples of terminologies. It is worth observing at this point that there are no presentations of terminologies in the older sources, if we disregard Leem's distinction between noai'de and judakas/juraak or Skanke's between noai'de and guaps (cf. 2.1 above). The authors of the written sources did know about different types of noai'de's but have nothing to say about the words used for the different types; that there were lesser and stronger ones was known by Hans Skanke (Skanke [1728] 1945, 207f.) and Jens Kildal (Kildal [1730] 1945, 136-140), and Skanke (Skanke [1728] 1945, 208) states that "the Lapps were of the opinion that there were grades in the perfection of the noai'de's'. The terminologies of other peoples in northern Eurasia discussed by Bäckman (Bäckman 1978, 62-67) are then only comparable to the postshamanistic terminologies in Saami, as we know them from the later sources. The problems for the study of Saami shamanism that these changes of meaning imply, have, as I have already stated, been to a great extent overlooked in the study of Saami religion.

I have chosen three examples of terminologies where noai' de occurs in a postshamanistic context, i.e. in connection with words denoting other types 

i. sorcerer
ii. used the drum, an ecstatic
iii. name related to the name of a god

$\begin{array}{llll} & \mathrm{i} & \mathrm{ii} & \mathrm{iii} \\ \text { niei'te } & + & 0 & - \\ \text { kiemdesniei'te } & + & + & - \\ \text { kāirve } & + & 0 & +\end{array}$

Fig. 1 .

of 'sorcerers', 'diviners' etc. The examples are from Yokanga (lpTer), Kautokeino (lpN) and Gällivare (lpL).

\subsection{Yokanga, 1914 (Ter Saami)}

During his journey in the Kola Peninsula in 1914, Toivo I. Itkonen collected Ter Saami words in Yokanga for two weeks in July (Itkonen 1958, XV-XVI). Among them there are three words which in Finnish are translated as noita, the Finnish equivalent to Saami noai' de: niei'te, kiemdesniei'te and kāirve. The differences between the words are, according to Itkonen's translations, that niei'te (=noai'de) means 'sorcerer', kiemdesniei'te 'drum-, big, ecstatic sorcerer' (kiemdes is the Ter Saami word for the Saami drum), and käirve is connected with the god Kärva, but also used as invective. Although it is a little uncertain, as the information is rather summary, the differences in sense between these words could be presented in a table such as Fig. 1.'

It is unknown whether there were other words for 'sorcerer' in this dialect, but these three words provide, after all, an idea of distinctions that were made.

\subsection{Kautokeino, mid-19th century (Northern Saami)}

After the revolt in Kautokeino in November 1852, the eighteen-year-old Lars Jacobsen Hætta (1834-1897), one of the leaders, was imprisoned and brought to the Akershus fortress outside Kristiania. During his time in gaol he wrote an account of the religious and moral conditions in Kautokeino before the Læstadian revival, devoting one section to a presentation of different types of noai'de's. One could of course question whether the young Hætta had a full knowledge of the subject, but his text shows that he in spite of his youth, had a clear comprehension of the meaning of at least some words denoting different noai'de's.

\footnotetext{
${ }^{9}$ The tables and graphic representations have been inspired by the reading of Staib 1980. In the tables + means 'yes', - 'no' and 0 'no information available'.
} 


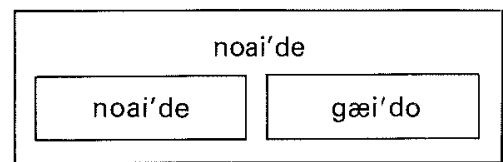

Fig. 2. i. could do evil to persons and things

ii. could kill

iii. diverted evil of other noai'de's

$\begin{array}{lccc}\text { noai'de } & \text { i } & \text { ii } & \text { iii } \\ \text { borânoai'de } & + & 0 & 0 \\ \text { guwlar } & + & + & 0 \\ \text { juovsâhæg'gje } & + & - & 0 \\ \text { gæi'do } & - & 0 & + \\ & - & 0 & 0\end{array}$

First, he distinguishes between two main types: noai'de and gai'do (Hætta [about 1860] 1982, 16). The word noai' de is used both as a comprehensive conception and as the name of one of the types. In a graphic representation this would be as in Fig. 2.

The main difference between the two types was, according to Hætta, that a noai'de could do evil to another person, something that a gai'do could not. But the gei'do's could perform wonders. "They could change themselves into animals or landareas, take burning coals in the fist, and rub them into scraps in the palms of the hands without burning their hands etc." (Hætta [about 1860] 1982, 19). Hætta even mentions that a chemist and druggist that came to the Finnmark was regarded as a kind of gai'do and consequently called stuorâ- or oai'vĕ-gæi'do 'the big or principal gæi $d o$ ' (Hætta [about 1860] 1982, 20).

The noai'de's, on the other hand, could do evil, and the strongest of these could even make another person die and were called bor're- or bor $\hat{a}$ noai'de's 'eater- or eating-noai'de's' while lesser ones, who could harm persons and property but not kill, were called guwlar's or goanstâšag'gje's. A third group was according to Hætta the juovsâhæg'gje's, who's task it was to divert the evil of other noai'de's (Hætta [about 1860] 1982, 16f.).

The distinctions between the different types are thus, according to Hætta, due to their different attitudes to and capacities concerning baha 'evil'. The distinctive features of the meaning of these words could then be summarized as in Fig. 3, and in a graphic representation the relations between the terms could be sketched as in Fig. 4.

\subsection{Gällivare, 1948 (Lule Saami)}

A different character appears in the different types of $1 \mathrm{pL}$ nåi'te that Johan Fankki has presented in a manuscript entitled Mui'htalus tålutj nåitij pirra 


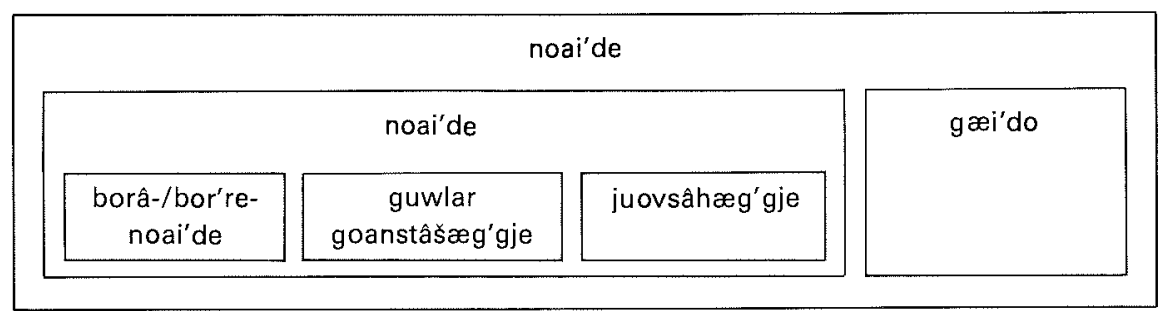

Fig. 4.

i. wicked

ii. frightened people with the help of the departed

iii. committed to the devil

$\begin{array}{lccc} & \text { i } & \text { ii } & \text { iii } \\ \text { piedjē-nåi'tē } & + & + & - \\ \text { sāvvē-năa'tē } & + & - & - \\ \text { ‘frimurar'-nåi'tē } & + & 0 & + \\ \text { tiwōō-năi'tē } & - & - & -\end{array}$

'A story about ancient nåi'te's', which is kept in the Dialect and Folklore Archives in Uppsala (acc. 19885). He distinguishes between four types. ${ }^{10}$ The first, the piedjē-nåi'te 'sender-nåi'te', was according to Fankki the worst. When this type of nai'te became angry he negotiated with the dead at the cemetery and then sent their spirits to frighten people and drive them out of their mind (ULMA 19885, 1). The sâvvée-nåi' te ' wisher-nåi'te' other hand, did not go to the cemetery or use the departed, but delivered curses on those he became angry with. In other respects he was, as Fankki states, "nearly the same kind of nåi'tē as the piedjē-nåi' $t \bar{e}$ " (ULMA 19885, 2). A third type was called "frimurar"-nåi'tè 'Freemason-nåi'tè' ("frimurar-" is Swedish). Fankki says that this nåi'te was wicked and had committed himself to the devil so that he could not become free (ULMA 19885, 3).

The tivvō-nåi'té 'a nåi'té that put right' was different. His task was to divert those spirits of the departed that the piedjē-nåi'tē had set on a person and he could also put other things right (ULMA 19885, 1f.).

Here the distinctions between the two first types are due to different attitudes to the departed and the third had surrendered himself to the devil. The fourth one, in contrast to the other three, was not wicked. To summarise in a table, the result would be something as in Fig. 5 .

${ }^{10}$ It should be noted that I present the four types in a different order to Fankki. 


\subsection{Some concluding remarks}

If we compare the three examples, it is clear that the terminologies differ, but also that there are certain similarities. One obvious distinction drawn both in Kautokeino and in Gällivare is between the wicked and the good noai'de. This can be compared with Fellman's information that the Saamis divided their noai'de's into two groups, those that released men from sorcery and those that used their magic to harm other people (Fellman 1906, 28 f.), a Saami equivalent to the distinction between the so called "black" and "white" shamans among some Siberian peoples (cf. Eliade 1972, 184-189).

Another similarity is that the different types are classified in terms of strength, although the criteria differ. The noai' de that is most powerful is in Yokanga the one who uses the drum to attain ecstacy, in Kautokeino the one who can kill and in Gällivare the noai'de who is assisted by the departed. It seems as though different elements of the shamanistic ideology, as it is known from the earlier sources, have been preserved in the different regions.

\section{Change of reality and change of meaning}

In the same way as the importance of spatial differentiation in the study of Saami culture has been stressed by Juha Pentikäinen (Pentikäinen 1973), it is also important to be conscious of temporal differentiation. The changes are not sudden, but gradual (although of varying rapidity at different periods and in different regions). In addition, the Saami religion that we meet in the sources from the 17th and 18th centuries was in the process of change. There is certainly no "pure" Saami religion to draw conclusions about from the available source material.

It is imporant, to emphasize both the difference between internal and external understandings and the change in the internal Saami understanding of the word noai'de (cf. Bäckman 1982, 122f.):

In pre-Christian Saami society, where shamanism was an important (maybe the most important) element of religion, noai' de was the word used for the outstanding religious functionary, the shaman. The noai'de was, in a state of ecstacy, able to make journeys to distant places and to the worlds of the gods or the departed to achieve help in times of crisis; he was curer and diviner and could also function as sacrifical priest (Hultkrantz 1978).

From outside, on the other hand, even Saamis in general were looked upon with great suspicion and considered as 'sorcerers' (cf. Nesheim $1970 \mathrm{~b}$ ). From the 18th century the sources began to focus on the noai'de, 


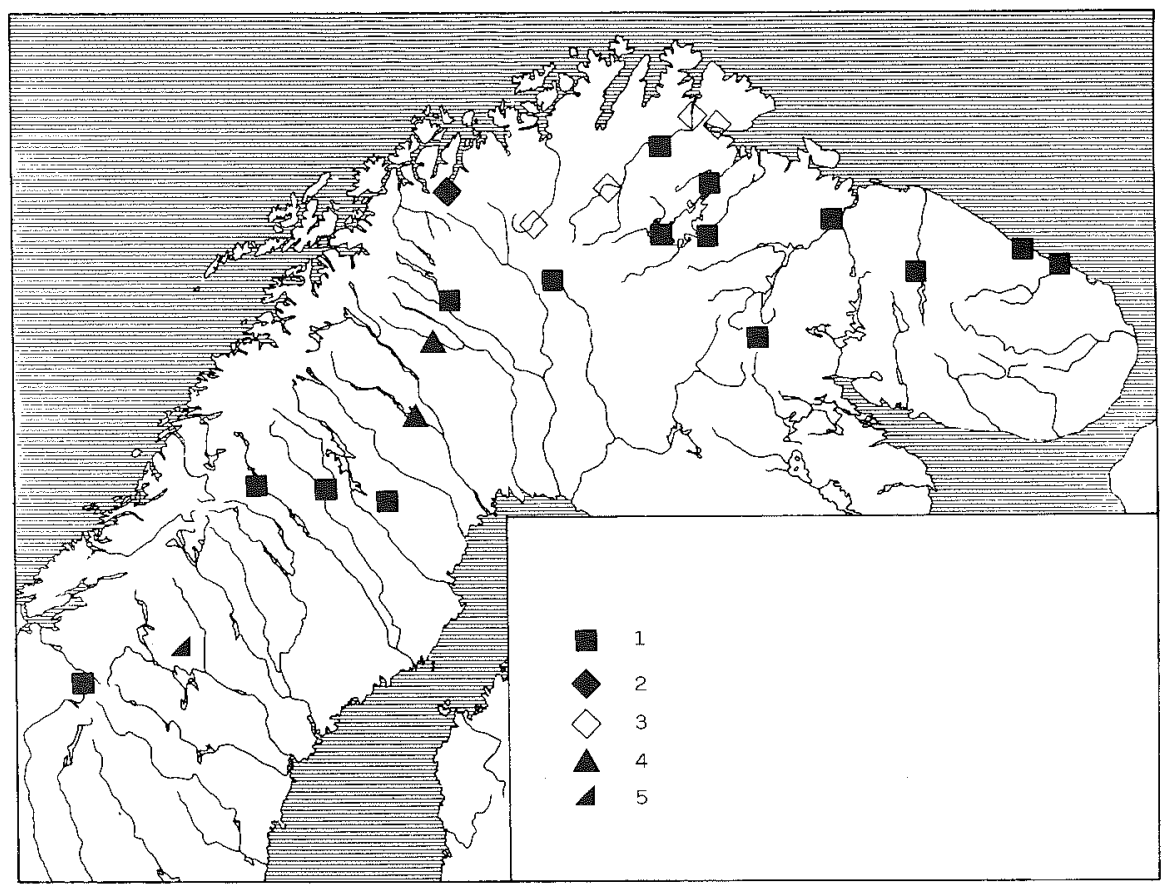

Fig. 6. Atlas Linguarum Europae. Premier questionnaire. Answers to question 503, la sorcière 'witch'. 1 = noai' de (cf. 2.3 .1 ); 2 = noai' děak'ko 'old noai' de-woman'; 3 = noai'děak'ka 'noai' de-wife'; $4=1 \mathrm{pL}$ kuopas (cf. 2.3.2); $5=\mathrm{lpS}$ ruvtege 'female phantom, witch'.

Source: FU Archive of Atlas Linguarum Europae, Saami department.

whose activities were regarded as 'sorcery', whilst he himself was seen as the 'sorcerer' par préférence.

The other aspect is the change in the internal Saami view of the noai'de. The pre-Christian Saami religion, with its special anthropology and cosmology, was a necessary prerequisite for the noai'de. Without this context, the noai'de could not function and only some minor elements of curing and divining could survive the religious change. This change of reality changed the meaning of the word noai'de in Saami consciousness. The new meaning came in accordance with the outside understanding of the meaning of the word, and noai' de became, in the postshamanistic terminologies, one term among many others for 'diviner', 'sorcerer' etc.

This change of meaning has continued. An interesting example of the current state of this change is illustrated by the answers to question 503 (la sorcière 'witch') in the first questionnaire of Atlas Linguarum Europae. The 
Saami correspondence to the word, explained as "a woman that practices a secret, unpermitted and dreadful magic, calling together the departed and the evil spirits" (Weijnen et al. 1976, 84), is in most of the dialects noai'de (cf. Fig. 6)! It seems then that this word, in the process of change of meaning, may now also be used for women.

There are also, however, examples of other changes in meaning. Lagercrantz (Lagercrantz 1939, 529) noted for instance that lpL nåi'té as a secret word was used with the meaning 'clock' in Tysfjord in the phrase lpL kallen nåi'té? 'what time [is it]'?.

Furthermore, and this is the crucial point, these changes of meaning involve risks for the student of both shamanism and postshamanism, as they bring into focus the question of the availability of different sources. The tendency for words used for phenomena in the old religion (and thereby in shamanism) -as far as we know them-to be Finno-Ugric and for words used in the magic of postshamanistic time to be loans is certainly a warning against drawing over hasty conclusions on Saami shamanism from later sources, but does not mean that we can be sure that there were no loanwords in the shamanistic terminologies. The negative evaluation of the noai' $d e$ in the earlier sources, makes it even more difficult to interpret the role of the noai'de in pre-Christian Saami religion.

Finally, there is the general problem of the relation between the (religious) terminology of shamanism and the (magic) terminology of postshamanism. ${ }^{11}$ I have stressed the religious roles of the noai'de as shaman in contrast with the noai' de as diviner in the magic of postshamanism, and, in a way, the word noai'de may be said to bridge the gap between religion and magic, as it is found in both areas. The terms of noai'děvuottâ are then, valuable not only in the study of Saami religious changes, but should also be taken into consideration in the discussion of the definitions of religion and magic.

\section{Bibliography}

\section{UNPUBLISHED SOURCES}

\section{Uppsala}

ULMA Dialekt- och folkminnesarkivet i Uppsala

19885 Fankki, J. Mui'htalus tålutj nåitij pirra.

FU Finsk-ugriska institutionen

Archive of Atlas Linguarum Europae, Saami department.

${ }^{11}$ The best treatise on Saami magic is still in my opinion the surprisingly sympathetic chapter on this subject in Lars Levi Læstadius' Fragmenter i Lappska mythologien ('Fragments in Lappish mythology': Læstadius [1840-1845] 1958, 88-126). 


\section{PUBLISHED SOURCES AND LITERATURE}

Äimä, F. 1932. Russ. кебовать-lp. gievvot. Annales Academiae Scientiarum Fennicae B, 27. Helsinki.

Bäckman, L. 1978. Types of shamanism: comparative perspectives. Studies in Lapp shamanism. By L. Bäckman \& $\AA$. Hultkrantz. (Stockholm Studies in Comparative Religion 16.) Stockholm.

Bäckman, L. 1982. The noajdie and his ecstasy. Religious ecstasy. Ed. by N. G. Holm. (Scripta Instituti Donneriani Aboensis 11.) Stockholm.

Bergsland, K. 1942. Det samiske slektskaps- og svogerskapsordsystem. Norsk tidsskrift for sprogvidenskap 13. Oslo.

[The Bible]. 1811. Tat Ailes Tjalog [...] Hernösand.

[The Bible]. 1895. Bibal daihe Basse čala [...] Kristiania.

Collinder, B. 1977. Fenno-Ugric vocabulary. Hamburg.

Eliade, M. 1972. Shamanism. Princeton.

Falkenberg, J. 1953. Slektskapssystemet hos Snåsa-samene. Studia septentrionalia 5. Oslo.

Fellman, J. 1906. Anteckningar under min vistelse i lappmarken 2. Helsingfors.

Grundström, H. 1946-54. Lulelapsk ordbok-Lulelappisches Wörterbuch. (Skrifter utgivna genom Landsmåls- och Folkminnesarkivet i Uppsala C, 1.) Uppsala.

Hætta, L. J. 1982. Muitalus. Muitalusat. [By] L. Hætta \& A. Baer. [Ed. by] T. Frette. Troms $\phi$.

Hansegård, N.-E. 1978. The transition of the Jukkasjärvi Lapps from nomadism to settled life and farming. (Studia Ethnographica Upsaliensia 39.) Uppsala.

Hasselbrink, G. 1981-85. Südlappisches Wörterbuch-Oårj' elsaamien baaguog'ärjaa 1-3. (Skrifter utgivna genom Dialekt- och Folkminnesarkivet i Uppsala C, 4.) Uppsala.

Hultkrantz, A. 1973. A definition of shamanism. Temenos 9 .

- 1978. Means and ends in Lapp shamanism. Studies in Lapp shamanism. By L. Bäckman \& $\AA$. Hultkrantz. (Stockholm Studies in Comparative Religion 16.) Stockholm.

Itkonen, T. I. 1946. Heidnische Religion und späterer Aberglaube bei den finnischen Lappen. (Mémoires de la Société Finno-Ougrienne 87.) Helsinki.

- 1958. Koltan- ja Kuolanlapin sanakirja-Wörterbuch des Kolta- und Kolalappischen. (Lexica Societatis Fenno-Ugricae 15.) Helsinki.

Jessen, E. J. 1767. Afhandling om de Norske Finners og Lappers Hedenske Religion. Kiøbenhavn.

Kalima, J. 1930. Eräästä lappalaisnoidan nimityksestä. Virittäjä 44.

Kapelrud, A. S. 1967. Shamanistic features in the Old Testament. Studies in shamanism. [Ed. by] C.-M. Edsman. (Scripta Instituti Donneriani Aboensis 1.) Stockholm.

Kharuzin, N. 1890. Русские лопари (Очерки прошлаго и современнаго быта). Москва.

Kildal, J. 1945. Afguderiets Dempelse, og den Sande Laerdoms Fremgang. [Ed. by] M. Krekling, Nordnorske samlinger 5. Oslo.

Kildeskrifter til den Lappiske Mythologi 1. 1903. [Ed. by] J. Qvigstad. (Det Kgl. Norske Videnskabers Selskabs Skrifter 1903, 1.) Trondhjem.

Kildeskrifter til den Lappiske Mythologi 2. 1910. [Ed. by] J. Qvigstad. (Det Kgl. Norske Videnskabers Selskabs Skrifter 1910, 4.) Trondhjem.

Korhonen, M. 1976. Suomen kantakielten kronologiaa. Virittäjä 80. 
Korol'kov, N. F. 1908. Трифоно-Печенгский монастырь, основанный преподобнымъ Трифономъ, проеветителемъ лопарей, его пазопение и возобвовление. С.-Петербургъ.

Læstadius, L. L. 1959. Fragmenter i Lappska Mythologien. [Ed. by] H. Grundström. Stockholm.

Lagercrantz, E. 1939. Lappischer Wortschatz 1-2. (Lexica Societatis Fenno-Ugricae 4.) Helsinki.

Leem, K. 1767. Beskrivelse over Finmarkens Lapper [...] Kiøbenhavn.

- 1768. Lexicon Lapponicum bipartium. Nidrosiae.

Lindahl, E. \& Öhrling, J. 1780. Lexicon Lapponicum [...] Holmiae.

Lundius, N. 1905. Descriptio Lapponiae. [Ed. by] K. B. Wiklund. Svenska Landsmål 17, 5. Uppsala.

Nesheim, A. 1947. Lappisk fiske og fisketerminologi 1. Studia septentionalia 3. Oslo.

- 1954. Den samiske grenevevningen og dens terminologi. Scandinavica et FennoUgrica. Stockholm.

- 1964. The Lapp fur and skin terminology and its historical background. Lapponica. (Studia Ethnographica Upsaliensia 21.) Uppsala.

- 1967. Duol'lje-čoar've-muorra. Sameslöjd-tradition och nydaning. Luleå.

- 1970a. Om noaiden, samenes sjaman. Norveg 14.

- $1970 \mathrm{~b}$. Samisk trolldom. Kulturhistoriskt lexikon för nordisk medeltid 15 . Helsingfors.

Nickel, K. P. 1984. Samisk grammatikk 3. S. 1.

Nielsen, K. 1932-38. Lappisk ordbok-Lapp dictionary 1-3. (Instituttet for sammenlignende kulturforskning $\mathrm{B}, 17,1-3$.) Oslo.

Nielsen, K. \& Nesheim, A. 1962-69. Lappisk ordbok-Lapp dictionary 4-5. (Instituttet for sammenlignende kulturforskning B, 17, 4-5.) Oslo.

Olsen, I. 1910. Om Lappernes Vildfarelser og Overtro. Kildeskrifter til den Lappiske Mythologi 2. [Ed. by] J. Qvigstad. (Det Kgl. Norske Videnskabers Selskabs Skrifter 1910, 4.) Trondhjem.

Pentikäinen, J. 1973. The division of the Lapps into cultural areas. Circumpolar problems. (Wenner-Gren Center International Symposium Series 21.) Exeter.

Qvigstad, J. 1893. Nordische Lehnwörter im Lappischen. (Christiania VidenskabsSelskabs Forhandlinger for 1893, 1.) Christiania.

- 1927. Lappiske eventyr og sagn 1. Oslo.

Qvigstad, J. \& Wiklund, K. B. 1899. Bibliographie der lappischen Litteratur. (Mémoires de la Société Finno-Ougrienne 13.) Helsingfors.

Randulf, J. 1903. Relation anlangende Find-Lappernis [...] afGuderier og Sathans dyrkelser [...] Kildeskrifter til den Lappiske Mythologi 1. [Ed. by] J. Qvigstad. (Det Kgl. Norske Videnskabers Selskabs Skrifter 1903, 1.) Trondhjem.

Rheen, S. 1897. En kortt Relation om Lapparnes Lefwarne och Sedher [...] [Ed. by] K. B. Wiklund. Svenska Landsmål 17, 1. Uppsala.

Ruong, I. 1945. Studier i lapsk kultur i Pite lappmark och angränsande områden. Svenska Landsmål 1943-44. Uppsala.

- 1964. Jåhkåkaska sameby. Svenska Landsmål 1964. Uppsala.

- 1982. Samiska benämningar på icke-samer. Språkhistoria och språkkontakt $i$ Finland och Nord-Skandinavien. (Kungl. Skytteanska Samfundets Handlingar 26.) Umeå.

Sammallahti, P. 1982. Lappish (Saami) hunting terminology in an historical perspec- 
tive. The hunters. Ed. by $\AA$. Hultkrantz \& Ørnulf Vorren. (Troms $\emptyset$ Museum Skrifter 18.) Troms $\emptyset$.

Schlachter, W. 1958. Wörterbuch des Waldlappendialekts von Malå und Texte zur Ethnographie. (Lexica Societatis Fenno-Ugricae 14.) Helsinki.

Skanke, H. 1910. Epitomes Historiae Missionis Lapponicae. Fjerde anhang. Källskrifter till lapparnas mytologi. [Ed. by] E. Reuterskiöld. (Bidrag till vår odlings häfder 10.) Stockholm.

Skanke, H. 1945. Epitomes Historiae Missionis Lapponicae. Pars Prima. [Ed. by] O. Solberg. Nordnorske samlinger 5 . Oslo.

Staib, B. 1980. Semantik und Sprachgeographie. Tübingen.

Toivonen, Y. H. et al. 1955-81. Suomen kielen etymologinen sanakirja 1-7. (Lexica Societatis Fenno-Ugricae 12.) Helsinki.

Weijnen, A. et al. 1976. Atlas Linguarum Europae (ALE). Premier questionnaire [...] Préparé par J. Kruijsen. Assen.

Whitaker, I. 1979. The kinship and affinal terminology of the Karesuando Lapps (Sámi). Finnish-Ugrische Forschungen 43. Helsinki.

Wickman, B. 1965. The origin of the Lappish hunting and fishing terminology. Hunting and fishing. Ed. by $\mathrm{H}$. Hvarfner. Luleå.

Widengren, G. 1969. Religionsphänomenologie. Berlin. 